Editon Consortium Publishing

Transforming Scholarly Publishing

\section{Editon Consortium Journal of Business}

and Management Studies (ECJBMS)

Volume: 02 Issue: 01 | Jan-April-2020

ISSN: $2664-9470$

Received: 25.02.2020; Accepted 30.03.2020; Published: 10.04.2020 at www.editoncpublishing.org

George Gachuru, Editon Cons. J. Bus. Manag. Stud.-Blind Peer Reviewed Journal

\title{
Effect of Customer Security on Performance of Online Banking on Microfinance Institutions in Nakuru Town, Kenya
}

\author{
George Gachuru \\ St. Paul's University, Kenya \\ Email address: gachuru2000@gmail.com
}

\begin{abstract}
The study aimed at determining the effect of customer security on the performance of online banking on microfinance institutions in Nakuru CBD. The study is significant to the Microfinance Institutions in that; it will benefit management and staff of MFI and the government understudy by gaining insights into how their institution can effectively deal with the challenges that they face in managing their clients and ensuring they grow their business. The increasing number of consumers of online banking shows that the level of adoption of online banking has improved. Several variables can influence the amount of adoption of online banking. The researcher used survey design where the target population comprised of 35 respondents. These were Branch managers, Chief Credit officer/s and the IT support of the MFI in Nakuru CBD. The study used census method, and a questionnaire containing closed-ended questions was used as the data collection instrument for the research. Descriptive statistics were used in data analysis and presentation of the results was in the form of tables, charts and graphs. The findings revealed that security affects the implementation of online banking to a large extent. Based on this finding, the researcher recommended that Microfinance Institutions should improve on issues concerning customer security in that, there should be no delay. The researcher suggested further study should be done on factors affecting adoption of M-Pesa money transfer bill payment.
\end{abstract}

Key terms: Online banking, Micro Finance, Institutions

$* * *$

How to cite this article in APA ( $6^{\text {th }}$ Edition)

Gachuru, G. (2020). Effect of customer security on performance of online banking on microfinance institutions in Nakuru town, Kenya. Editon Cons. J. Bus. Manag. Stud., 2(1), 49-55. 


\section{Editon Consortium Journal of Business and Management Studies (ECJBMS)}

Volume: 02 Issue: 01 | Jan-April-2020

ISSN: $2664-9470$

Received: 25.02.2020; Accepted 30.03.2020; Published: 10.04.2020 at www.editoncpublishing.org

George Gachuru, Editon Cons. J. Bus. Manag. Stud.-Blind Peer Reviewed Journal

\section{Introduction}

The annual growth of internet banking has been 80 per cent since 2014. Currently, more than 100 million households worldwide bank online, and 25 per cent of American households have adopted internet banking (Polatoglu \& Ekin, 2001). Internet banking has gained ground as a new opportunity for banking institutions in a world that is becoming increasingly globalised through the use of the Internet and the World Wide Web. These new opportunities and challenges have resulted in new competitors in the global banking market (Suganthi, Guru, \& Balachandran, 2001).

According to the World Bank, in the development of microfinance institutions, Africa as a continent has been left behind, thus tending to be smaller and less advanced compared to those in Asia and Latin America. However, the goal of microfinance programs globally has a common factor. Microfinance programs are often designed for the poor, the majority of whom are women and youth (Cheston, 2014).

Online banking provides banks with the opportunity to provide services through computer networks and customers to access services without physical contact with bank branches, based on the internet. On banking, it was regarded as a portal \& Banking services delivery and usage. Online banking involves some services provided by the bank and consumed through the internet by the client. Such services can be generally offered services, request services, transfer of third-party payments funds and investment are categorised. Online account services include self-service technology that allows customers to open, modify, close and retrieve information without physical contact from their account (Cheston, 2014).

Third-party payment facilities enable clients to instruct their banks to make electronic payments on their fund transfer services from one account to another. In contrast to traditional online transfers, inter-or intra-bank transfers where clients visit bank branches to finish forms, online banking allows them to do so without physical contact via the internet. Customers can access account data at any moment, day or night through online banking, and this can be achieved from anywhere. Online banking has enhanced the effectiveness of banking in rendering customer services.

Different researchers have argued that small-scale entrepreneurs in democratic societies have a right to the participatory role and full ownership of MFI organisations, including planning, management and decision-making (Shakya, 2016). The foundation of the argument Unknown to formal specialists, entrepreneurs, has access to historical understanding. The followers of this school of thought asserted that MFI should not be run by organisations of the public sector, but should be handed over to small farmers to create a feeling of ownership among small-scale farmers (Sharma \& Nepal, 1997). Extensive experience and study have demonstrated the significance of savings and credit services for bad, micro and tiny businesses. This emphasises the development of MFI as vital ingredients for investment, employment and economic growth. There is considerable potential for using Kenya's institutional credit and other financial services to alleviate poverty (Omino, 2005). Historically, microfinance has succeeded in achieving the excluded population from the conventional financial system. The microfinance organisations focused their efforts on economic and institutional sustainability. Tools have been created to assess economic performance, but social performance has been taken for granted.

\section{LITERATURE REVIEW}

Karjaluoto, Mattila, and Pento (2002) stated that safety was commonly acknowledged as one of the primary obstacles to IB implementation in Finland. Moreover, 


\section{Editon Consortium Journal of Business and Management Studies (ECJBMS)}

Volume: 02 Issue: 01 | Jan-April-2020

ISSN: $2664-9470$

Received: 25.02.2020; Accepted 30.03.2020; Published: 10.04.2020 at www.editoncpublishing.org

George Gachuru, Editon Cons. J. Bus. Manag. Stud.-Blind Peer Reviewed Journal

Khalfan, AlRefaei, and Al-Hajery (2006), and Al-Sabbagh and Molla (2004), also pointed out that safety concerns were one of the significant problems in the Omani banking industry e-bank adoption. Khan, Abid and Noreen (2015) argued that cash cultivation is still conventional in Pakistan relative to the substitute of plastic money adopted in most developed countries. They also stated the absence of confidence, lack of infrastructure; safety and service fees are the most important reasons. Sathye (1999) noted that 73 per cent of individuals prevented IB adoption because they are uncertain about the safety and safety of internet transactions, and Al-Alawi (2005) also put forward the same arguments. Many researchers have argued that the lack of trust is a critical issue that needs addressing the internet and E-commerce adoption.

According to Njenga's (2015) research of mobile banking experience in Kenya, the availability of various stores across the nation means more customer contact points than the traditional banking room set up. He also discovered that the M-Banking agents ' flexible working hours leave them more possibilities to meet banking demands that may occur at any moment. He also found that while the balance of mobile phones may seem low, the fact that there are balances shows that storage can be viewed as deposit recognition. This is a vital sign of the high importance attached to the comfort of using mobile payment facilities. Another research carried out in Kenya by Omwansa (2015) discovered that a lost or robbed mobile phone does not imply disaster because no one can access the internet. Omwansa also found that the perceived safety of online banking transactions is essential for customers in a mobile setting as one of the main issues. He observed that security is no delay, no incompleteness of transactions, and no disclosure of personal data during transactions. Mobile banking includes confidentiality authentication, data integrity and non-repudiation (Omwansa, 2015).
The enhanced amount of consumers of online banking shows that the level of adoption of online banking has improved. Several variables can influence the amount of adoption of online banking. One model is often used to define the acceptability level of perceived usefulness of technology and perceived usability is thought to be the foundation for determining technology adoption. Security is concerned with protecting the confidentiality, integrity and availability of three information characteristics through the use of technical solutions and management actions.

The vulnerabilities of all commercial operating systems are also known as computer system weakness. These vulnerabilities generate possibilities for potential threats to this system's data. From internal to external, human to non-human, and international to non-international, security threats can be classified into several categories. These threats may result in the opportunities of disclosing, modifying, and destroying or denying the use of that data and the multiple safety threats that data protectors need to be conscious of and account for (Cheston, 2014). When it comes to its influence on online banking acceptance, security is professed to be of paramount interest. But online confidence can be overcome if an adequate understanding of the variables that can boost customer confidence in online banking is well observed. In a study undertaken by computer fraud and safety, 82 per cent of clients doubted answering their banks ' messages, 52 per cent more said they would dismiss any internet banking sign-ups, meaning that more clients are now anxious about online banking safety.

Online banking is a significant move for many clients as it is common for clients to simply go to their computers, at home or work and log on to the online banking site, then clients can swap cash from one account to the other and pay bills by pressing a button. As more online banking technology increases, safety appears to become tighter. There are still opportunities for hacking the account you're 


\section{Editon Consortium Journal of Business and Management Studies (ECJBMS)}

Volume: 02 Issue: 01 | Jan-April-2020

ISSN: 2664-9470

Received: 25.02.2020; Accepted 30.03.2020; Published: 10.04.2020 at www.editoncpublishing.org

George Gachuru, Editon Cons. J. Bus. Manag. Stud.-Blind Peer Reviewed Journal

going on. There are always opportunities to decrease fraud risk. Every time you log on to the internet, your computer is at risk of various threats to obtain your personal information and access your money. Behind the scene, various security measures are used to ensure that it is protected and safe for transactions and personal information (Cheston, 2014). The client can, however, also play a significant role in safeguarding banking and private data. The first step is to understand the computer's primary threats. If consumers are unaware that criminals are actively targeting their private data, they may lack the standpoint necessary to define phasing threats and may not take adequate defense when carrying out internet operations. Such factors influence why their online banking safety concerns clients.

\section{METHODOLOGY}

The study adopted a survey research design. The target population comprised of 35 respondents, these were branch managers, Chief Credit officer/s and the IT support of the MFI in Nakuru CBD. The sampling frame of this study was established based on the respondents' relevancy to the topic under investigation. The study identified ten microfinance institutions which have a population of 35 employees in the relevant departments of the Branch managers, Chief Credit officer/s and the IT support of the MFI in Nakuru CBD. The study used census method. The study also made use of primary data that was obtained using open-ended questionnaires. The main data collection instruments were questionnaires with structured questions. The researcher sought permission from the heads accounts, procurement and auditing to conduct the study. The researcher subjected 10\% (4) of the draft questionnaires to a pilot test on the residents of KenGen Naivasha. The supervisor of this study ensured the validity of instruments. Reliability of the instruments was determined through a pilot study of five questionnaires. The methods that were used in the analysis of the research data are of descriptive statistics in nature. This is made up of percentages. Findings were presented using tables.

\section{ANALYSIS AND PRESENTATION}

Effects of Customer Security on Performance of Online Banking

The study wanted to establish whether customer security affects the performance of online Banking on MFIs. The findings are as illustrated in Figure 1.

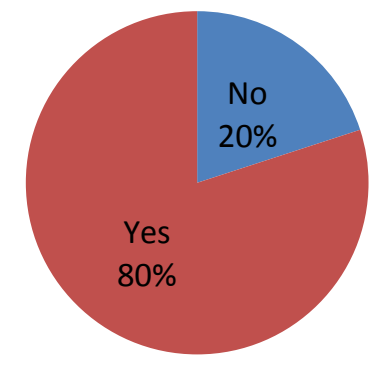

Figure 1: Effects of customer security on the performance of online banking Source: Research Data (2019) 
Editon Consortium Publishing

Transforming Scholarly Publishing

\section{Editon Consortium Journal of Business}

and Management Studies (ECJBMS)

Volume: 02 Issue: 01 | Jan-April-2020

ISSN: $2664-9470$

Received: 25.02.2020; Accepted 30.03.2020; Published: 10.04.2020 at www.editoncpublishing.org

George Gachuru, Editon Cons. J. Bus. Manag. Stud.-Blind Peer Reviewed Journal

According to the findings, 80 percent of the respondents agreed that customer security affects the performance of online Banking in MFIs, 20\% disagreed. None of the Respondent said they don't know. This implies that customer security affects the performance of online Banking system in MFI.
The extent to which Customer Security Affect Performance of Online Banking

The study wanted to determine the extent to which customer security affect the performance of online Banking in MFIs. The findings are as illustrated in Table 1.

Table 1: Extent to which Customer Security Affect Performance of Online Banking

\begin{tabular}{|l|l|l|}
\hline Extent & Frequency & Percentage (\%) \\
\hline Large extent & 15 & 50 \\
\hline Very large extent & 10 & 33 \\
\hline Undecided & 0 & 0 \\
\hline Very small extent & 0 & 0 \\
\hline Small extent & 5 & 17 \\
\hline Total & 30 & 100 \\
\hline
\end{tabular}

Source: Research Data (2019)

According to the findings, $50 \%$ said that customer security would affect the performance of online Banking at a large extent, $33 \%$ said it would affect at a very large extent, $0 \%$ were undecided $0 \%$ at a very small extent, and $1 \%$ at a small extent implies that customer security will affect the performance of online Banking at a large extent.
Effects of Customer Security on Performance of Online Banking

The study wanted to find out the effects of level of skills on the performance of online Banking in MFIs. The findings are as illustrated in Table 2.

Table 2: Effects of Customer Security on Performance of Online Banking

\begin{tabular}{|l|l|l|l|l|l|}
\hline & S. Agree & Agree Disagree & Disagree & S. Disagree & Disagree \\
\hline $\begin{array}{l}\text { Perceived customer security of online } \\
\text { Banking transaction is necessary as one of the } \\
\text { primary concern for the users }\end{array}$ & $13(43 \%)$ & $12(40 \%)$ & $5(17 \%)$ & $0(0 \%)$ & $0(0 \%)$ \\
\hline $\begin{array}{l}\text { Customer security represents no delay, no } \\
\text { transaction incompleteness and no private } \\
\text { information disclosure during Transaction }\end{array}$ & $6(20 \%)$ & $15(50 \%)$ & $9(30 \%)$ & $0(0 \%)$ & $0(0 \%)$ \\
\hline $\begin{array}{l}\text { Customer security is a strong factor that } \\
\text { relates to the reluctance of using the internet } \\
\text { for transactions }\end{array}$ & $10(33 \%)$ & $17(47 \%)$ & $3(10 \%)$ & $0(0 \%)$ & $0(0 \%)$ \\
\hline
\end{tabular}

Source: Research Data (2019) 


\section{Editon Consortium Journal of Business and Management Studies (ECJBMS)}

Volume: 02 Issue: 01 | Jan-April-2020

ISSN: 2664-9470

Received: 25.02.2020; Accepted 30.03.2020; Published: 10.04.2020 at www.editoncpublishing.org

George Gachuru, Editon Cons. J. Bus. Manag. Stud.-Blind Peer Reviewed Journal

On whether perceived customer security of online Banking transaction is necessary as one of the primary concern for the users, $43 \%$ strongly agreed, 40\% agreed, $17 \%$ disagree, $0 \%$ strongly disagree, and $0 \%$ don't know. On whether customer security represents no delay, no transaction incompleteness, and no private information disclosure during Transaction 20\% strongly agree, 50\% Agree, 30\% Disagree $0 \%$ strongly Disagree, and $0 \%$ Don't know. Regarding whether customer security is a strong factor that relates to the reluctance of using the internet for transactions, $33 \%$ strongly agree, $47 \%$ agree, $10 \%$ Disagree $0 \%$ strongly Disagree, and 0\% Don't know. This implies that perceived customer security of online banking transaction is necessary as one of the primary concern for users, it also implies that customer security represents no delay, no transaction incompleteness, and no private information disclosure during Transaction it also implies that customer security is a strong factor that relates to the reluctance of using the internet for transactions.

\section{CONCLUSIONS AND RECOMMENDATIONS}

The researcher concluded that customer security affects the performance of online banking at a large extent. The findings also revealed that perceived customer security of online banking transaction is necessary as one of the primary concern for the users. The results further showed that customer security is a strong factor that relates to the reluctance of using the internet for transactions. The researcher recommended that Microfinance Institutions should improve on issues concerning customer security in that there should be no delay, no transaction incompleteness and no private information disclosure during a transaction since customer security is a strong factor that relates to the reluctance of using the internet for transactions.

\section{References}

Al-Alawi, A. I. (2005). Adoption and awareness of online banking issue among mature users. Asian Journal of Information Technology 4(9), 856-860.

Al-Sabbagh, I., \& Molla, A. (2004). Adoption and use of internet banking in the sultanate of Oman: An exploratory study. Journal of Internet Banking and Commerce. 9(2).

Cheston, S. (2014), Women's empowerment and microfinance. Department of sociology. Yale University.

Karjaluoto, H., Mattila, M., \& Pento, T. (2002). Factors underlying attitude formation towards online banking in Finland. International Journal of Bank Marketing. 20(6). 261-272.

Khalfan, A. M. S., AlRefaei, Y. S., \& Al-Hajery, M. (2006). Factors influencing the adoption of internet banking in Oman: A descriptive case study analysis. International Journal of Financial Services Management, 1(2-3), pp.155-172.

Khan, R. E. A., Abid, R. G., \& Noreen, S. (2015). Financial development and poverty in Pakistan: Causality analysis. Archives Des Sciences, 65(11). Available at SSRN: https://ssrn.com/abstract=2551411

Njenga, A. D. K. (2015). Influence of mobile banking on growth of Microfinance Institutions in Kenya. Unpublished project KIM.

Omino, G. (2005). Regulation and supervision of Microfinance Institutions in Kenya. Available at www. Cgap.org

Omwansa, T. K. (2015). Internet banking: Market development and regulatory issues. Society of Government economists. Washington D.C. 


\section{Editon Consortium Journal of Business and Management Studies (ECJBMS)}

Volume: 02 Issue: 01 | Jan-April-2020

ISSN: $2664-9470$

Received: 25.02.2020; Accepted 30.03.2020; Published: 10.04.2020 at www.editoncpublishing.org

George Gachuru, Editon Cons. J. Bus. Manag. Stud.-Blind Peer Reviewed Journal

Polatoglu, V. N., \& Ekin, S. (2001). An empirical investigation of the Turkish consumers' acceptance of Internet banking services. International Journal of Bank Marketing, 19(4), 156-165.

Sathye, M. (1999). Adoption of internet banking by Australian consumers: An empirical investigation. International Journal of Bank Marketing, 17(7), pp. 324-334.

Shakya, K. (2016). Microfinance and women empowerment. Degree Thesis, Arcada.

Sharma, S. R., \& Nepal, V. (1997). Strengthening of credit institutions /programs for rural poverty alleviation in Nepal. United Nations, Economic and Social Council (ECOSOC) for Asia and Pacific, Bangkok, Thailand.

Suganthi, R., Guru, B., \& Balachandran (2001). Internet banking patronage: An empirical investigation of Malaysia. Journal of Internet Banking and Commerce, 6(1). 